\title{
Influence of soil characteristics on rare earth fingerprints in mosses and mushrooms: Example of a pristine temperate rainforest (Slavonia, Croatia)
}

\author{
Željka Fiket ${ }^{\mathrm{a},{ }^{*}}$, Gordana Medunić ${ }^{\mathrm{b}}$, Martina Furdek Turk ${ }^{\mathrm{a}}$, Maja Ivanić ${ }^{\mathrm{a}}$, \\ Goran Kniewald ${ }^{\text {a }}$ \\ ${ }^{a}$ Ruðer Boškoviæ Institute, Division for Marine and Environmental Research, Bijenièka 54, 10000 Zagreb, Croatia \\ ${ }^{\mathrm{b}}$ Faculty of Science, Department of Geology, Horvatovac 95, 10000 Zagreb, Croatia
}

\section{H I G H L I G H T S}

- Rare earths in soils, mosses and mushrooms of a pristine temperate rainforest.

- The REE in mosses and mushrooms primarily affected by soil characteristics.

- Mosses display soil signature with an insignificant REE fractionation.

- Mushrooms indicate an impact of soil organic content on the REEs uptake.

\section{A R T I C L E I N F O}

\section{Article history:}

Received 2 January 2017

Received in revised form

16 March 2017

Accepted 19 March 2017

Handling Editor: Petra Petra Krystek

\section{Keywords:}

Rare earth elements

Soil

Bio-monitoring

Moss

Mushroom

ICP-MS

\begin{abstract}
A B S T R A C T
The present study aims to investigate levels and distribution of rare earth elements (REE) in soils, mosses and mushrooms of a pristine temperate rainforest, a non-polluted natural system, in order to characterise their environmental availability and mobility. The multielement analysis of digested soil, moss and mushroom samples was performed by High Resolution Inductively Coupled Plasma Mass Spectrometry. The distribution of rare earths in mosses and mushrooms was found primarily affected by local pedological setting. Mosses displayed a consistent lithological signature with an almost insignificant REE fractionation compared to soils. Mushrooms showed differences in REE concentrations in certain parts of the fruiting body with regard to their main physiological function and indicated a significant impact of soil organic content on the overall REEs uptake. Results of our work highlight the importance of substrate characteristics on the initial levels of REEs in mosses and mushrooms. Moreover, this study provides baseline data on the rare earth element levels in mosses and mushrooms growing in a pristine forest area characterised by naturally elevated REE levels in the soil.
\end{abstract}

() 2017 Elsevier Ltd. All rights reserved.

\section{Introduction}

The increasing use of rare earth elements (REEs) for industrial and agricultural purposes during the last few decades resulted in their enhanced presence in the environment. Their future application is expected to expand even more, depicting them as emerging pollutants and calling for further research to upgrade our understanding of their chemical behaviour, bioavailability and geochemical interactions in various plant-soil systems (El-

\footnotetext{
* Corresponding author.

E-mail address: zeljka.fiket@irb.hr (Ž. Fiket).
}

Ramady, 2008). So far, research on biological and toxicological effects of the rare earths has been rather limited, and previous investigations suggest their negative physiological effects at elevated levels (Babula et al., 2008).

Most studies have focused on concentrations of REE in sediments, soils and vascular plants (Tyler, 2004; Semhi et al., 2009; Liang et al., 2005). Despite of many similarities, mechanisms of element uptake in vascular plants differ significantly from those in mosses and fungi (Kalač and Svoboda, 2000; Chiarenzelli et al., 2001; Onianwa, 2001; Das, 2005). Mushrooms, macroscopic fungi, take up elements from a substrate via spacious mycelium, whereas their content in fruiting bodies is considerably affected by 
age (Das, 2005). Additionally, particulate deposition in vascular plants and mushrooms is less important than in mosses due to reduced surface area and the dominant role of uptake from roots or mycelium and translocation to plant extremities (Chiarenzelli et al., 2001) or fruiting bodies (Das, 2005). Even though the mechanisms of assimilation and transportation of REEs in nonvascular plants are still poorly known, literature data suggest that both mosses and mushrooms have the ability to accumulate higher concentrations of REEs than some vascular plants, i.e. shrubs or coniferous trees (Chiarenzelli et al., 2001; Kalač and Svoboda, 2000; Dilna Damodaran et al., 2011). Due to different abilities of uptake and accumulation of metals from the substrate or air particles, these nonvascular plants have been utilised in various bio-monitoring and bio-remediation applications.

Compared to vascular plants, mushrooms can accumulate higher concentrations of heavy metals, such as lead, nickel, cadmium and mercury (Tuzen and Soylak, 2005; Sesli et al., 2008). Thus, they have been used for uptake and elimination of heavy metals from contaminated soil in a process referred to as mycoremediation (Kalač and Svoboda, 2000; Kalač, 2010 and references therein). Due to aerial structures consisting of large biomasses with tough texture and affinity towards metals and pollutants mushrooms act as biological filters and potential sorbents (Das, 2005; Marović et al., 2008; Dilna Damodaran et al., 2011). However, it was reported that bioaccumulation of heavy metals in macro fungi can be influenced by certain soil factors, i.e. presence of humus, $\mathrm{pH}$, metal concentration, etc. (Srivastava and Takur, 2006; Sesli et al., 2008; Falandysz et al., 2007).

Mosses, on the other hand, considered to be reliable biomonitors of the environment and of the air quality (e.g. Berg and Steinnes, 1997; Rossbach et al., 1999; Onianwa, 2001; Rühling and Tyler, 2004; De Nicola et al., 2013; Dołegowska and Migaszewski, 2013; Zechmeister et al., 2003; Vuković et al., 2015) as they uptake nutrients essentially from the atmosphere via wet and dry depositions. As such, mosses represent the most effective collector of fine atmospheric dust originating from dry depositions of both geogenic and anthropogenic sources (Marović et al., 2008; Gandois et al., 2014; Ćujić et al., 2014). So far, the distribution patterns and chemical behaviour of REEs in different moss species had been studied by Berg and Steinnes (1997), Chiarenzelli et al. (2001), Rühling and Tyler (2004, 2004) and Dołegowska and Migaszewski
(2013). They were considered to integrate a regional atmospheric signal, including both soil derived and industrially influenced atmospheric deposition (Gandois et al., 2014). However, relatively few REEs studies have been conducted in pristine forest ecosystems.

The present study was conducted in a protected area of a temperate rainforest, the last remnant of Slavonian (Croatia) rainforest (Mesić Kiš et al., 2016). The study area was selected as an example of a pristine soil-plant system, providing an opportunity to establish baseline concentrations of an area free of anthropogenic sources. Furthermore, according to the FOREGS geochemical data (Salminen et al., 2005), this area is characterised by naturally elevated levels of REEs. This provides an opportunity to study their distribution and fractionation in soil-moss and soil-mushroom system under initially elevated levels of rare earths.

The aim of this study was to report on levels and distribution of REEs in non-polluted natural soil-moss/mushroom systems in order to characterise their environmental availability and mobility, and contribute to the knowledge on their intake for future biomonitoring and bio-remediation studies as well as an assessment of anthropogenic pressures on natural systems.

The principal objectives of this study were as follows: 1) to assess the levels of REEs in soils, mosses and mushrooms of the Prašnik rainforest; 2 ) to provide an overview of spatial variations in REE abundance and fractionation patterns; 3) to determine the influence of soil properties on the uptake and the distribution of REEs in mosses and mushrooms, and 4) to present baseline concentrations of REEs in mosses and mushrooms grown in pristine forest environments.

\section{Materials and methods}

\subsection{Study area}

The Prašnik rainforest is located in Croatia (Fig. 1a), in the southwestern part of the Pannonian Basin System (Fig. 1b), in a subbasin known as the Sava Depression (Šparica et al., 1984). It is situated near the city of Stara Gradiška, approximately $0.5 \mathrm{~km}$ from the left bank of the Sava River, at an altitude of $96 \mathrm{~m}$, covering an area of 58 ha. The study area is covered with lacustrine-marshy and Quaternary sands, silts and clays whereas Pseudogley deposits, also

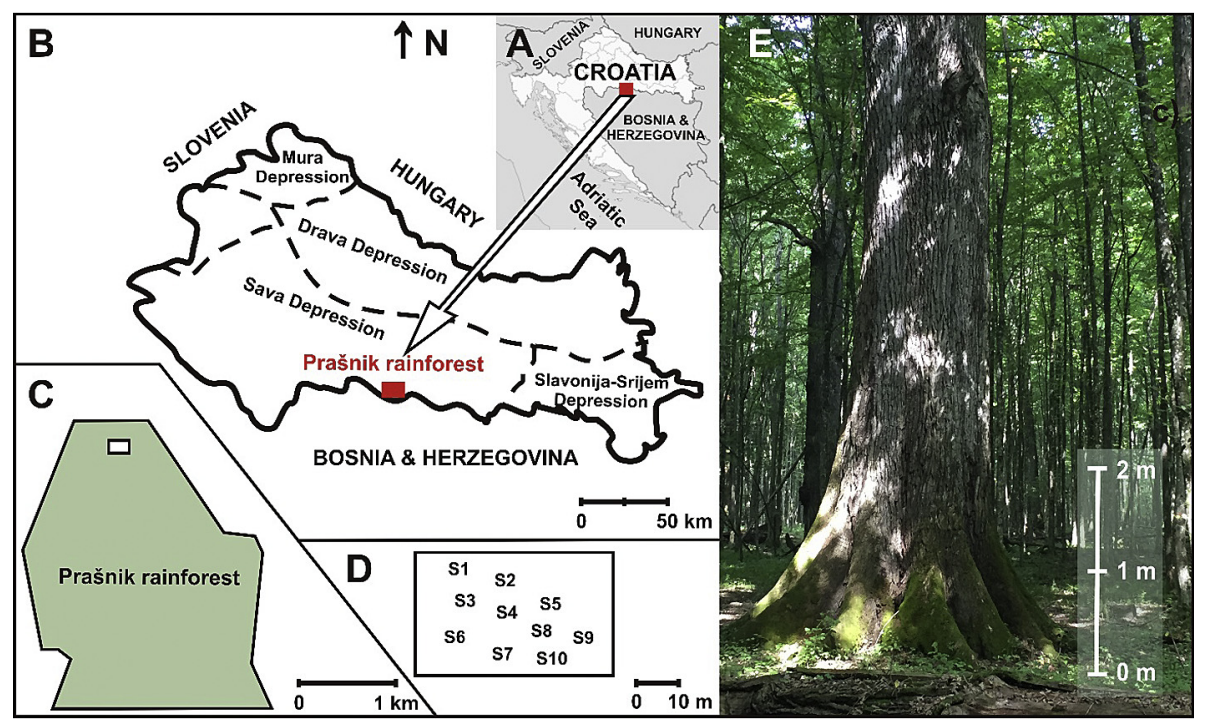

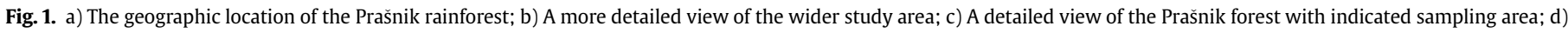
Distribution of sampling locations; e) An oak tree covered with moss. 
known as carbonate-reduced loess, are the dominant lithological unit (Bašić, 2013). Soil types were classified as Pseudogley and Eugley (Mesić Kiš et al., 2016 and reference therein). The forest is a unique phytocoenosis, protected as a special forest vegetation reserve since 1965, and is the last remnant of the Slavonian rainforest. However, because of the remaining mines from the war in the 1990s, the Prašnik rainforest is prohibited for visitors. Northwest, north, northeast and south borders of the Prašnik rainforest are in the near proximity of agricultural areas, separated from the forest by roads, low vegetation areas and the Sloboština stream channel. Further details of geological and pedological settings of the study area are reported elsewhere (Mesić Kiš et al., 2016).

\subsection{Sample collection and preparation}

Ten sampling locations were randomly selected within an area of approximately $1500 \mathrm{~m}^{2}$ inside the special forest vegetation area in the North Prašnik forest (Fig. 1c and d). At each location both soil (S1-S10) and moss (M1-M10) samples were collected. Soil samples represent the topsoil layer $(0-20 \mathrm{~cm})$. Moss samples were collected from tree trunks at a height of approximately $0.5-1 \mathrm{~m}$ (Fig. 1e), where available. In the laboratory, moss samples were carefully manually cleaned of soil particles, plant remains, and epiphytes. Additionally, two samples of above-ground mushrooms were collected at locations S2 and S3, hereinafter referred to as $F_{A}$ and $F_{B}$, respectively.

All soil samples were air-dried at $20^{\circ} \mathrm{C}$, sieved through a $2 \mathrm{~mm}$ sieve to remove the gravel fraction, homogenised using an agate mill, and stored until further analysis. All mosses and mushroom samples were air-dried, homogenised using an agate mill and stored until further analysis. Fruiting bodies of mushrooms were further divided into three subsamples (indexed as following: 1) lower stipes, 2) upper stipes, 3) pileus) to gain insight into the variability of metal concentrations along the mushroom tissue.

Prior to multielement analysis subsamples $(0.05 \mathrm{~g})$ of soils were subjected to total digestion in the microwave oven (Multiwave 3000 , Anton Paar, Graz, Austria) in a two-step procedure consisting of digestion with a mixture of $4 \mathrm{~mL}$ nitric acid $\left(\mathrm{HNO}_{3}, 65 \%\right.$, pro analysi, Kemika, Zagreb, Croatia) - $1 \mathrm{~mL}$ hydrochloric acid $(\mathrm{HCl}$, $36.5 \%$, pro analysi, Kemika, Zagreb, Croatia) - $1 \mathrm{~mL}$ hydrofluoric acid (HF, 48\%, pro analysi, Kemika, Zagreb, Croatia) followed by the addition of $6 \mathrm{~mL}$ of boric acid $\left(\mathrm{H}_{3} \mathrm{BO}_{3}\right.$, Fluka, Steinheim, Switzerland) (Fiket et al., 2016). After digestion soil samples were further diluted 10 -fold, acidified with $2 \%$ (v/v) $\mathrm{HNO}_{3}$ (65\%, supra pur, Fluka, Steinheim, Switzerland) and indium (In, $1 \mu \mathrm{gL}^{-1}$ ) was added as internal standard.

Subsamples $(0.1 \mathrm{~g})$ of mosses and mushrooms were subjected to digestion with $7 \mathrm{~mL}$ of $\mathrm{HNO}_{3}$ (65\%, supra pur, Fluka, Steinheim, Switzerland) and $0.1 \mathrm{~mL}$ of $\mathrm{HF}$ (48\%, pro analysi, Kemika, Zagreb, Croatia) (Filipović Marijić and Raspor, 2012). Similarly to soil samples, mosses and mushrooms digests were acidified with $2 \%(\mathrm{v} / \mathrm{v})$ $\mathrm{HNO}_{3}$ (65\%, supra pur, Fluka, Steinheim, Switzerland), but without further dilution and indium (In, $1 \mu \mathrm{g} / \mathrm{l}$ ) was added as internal standard.

\subsection{Physical and chemical characteristics of soil}

Soil $\mathrm{pH}$ was determined on a 1:5 soil to water suspension.

Organic matter (OM) content was determined using the loss on ignition (LOI) method (Schumacher, 2002). Loss on ignition (LOI) was determined gravimetrically after dry ashing at $375{ }^{\circ} \mathrm{C}$ over $24 \mathrm{~h}$. The specific surface area (SSA) was determined by a singlepoint nitrogen adsorption, using the Micromeritics FlowSorb II 2300 instrument. The cation exchange capacity (CEC) was determined using a barium chloride $\left(\mathrm{BaCl}_{2}\right.$, Kemika, Zagreb, Croatia) solution according to HRN ISO 11260:2012 (2012).

Measurements were conducted on native samples of soil from 10 locations. The results represent the average of two measurements.

\subsection{Analysis of rare earth elements in soil samples}

The multielement analysis was performed by High Resolution Inductively Coupled Plasma Mass Spectrometry (HR-ICP-MS) using an Element 2 instrument (Thermo, Bremen, Germany). Typical instrument conditions and measurement parameters used throughout the work were reported earlier (Fiket et al., 2016). Standards for multielement analysis were prepared by appropriate dilution of a multielemental reference standard (Analytika, Prague, Czech Republic) containing Ce, Dy, Er, Eu, Gd, Ho, La, Lu, Nd, Pr, Sm, $\mathrm{Tb}, \mathrm{Tm}, \mathrm{Y}$ and $\mathrm{Yb}$.

All samples were analyzed for the total concentration of 15 elements (Ce, Dy, Er, Eu, Gd, Ho, La, Lu, Nd, Pr, Sm, Tb, Tm, Y and Yb).

The quality control of analytical procedure used for REE analysis was performed by a simultaneous analysis of the blank and the certified reference material for soil (NCS DC 77302, also known as GBW 07410, China National Analysis Center for Iron and Steel, Beijing, China) and Rye grass (ERM-CD281). A good agreement between the analyzed and the certified concentrations within their analytical uncertainties $( \pm 10 \%)$ for all measured elements was obtained (Fiket et al., 2016).

\subsection{Statistical analysis}

Differences between groups regarding the level of REEs, including Y, were tested by analysis of variance (ANOVA) on ranks and subsequent pair wise comparison by Dunn's method (STATISTICA 8.0, Stat Soft Inc., USA), with a level of significance set at $\mathrm{p}<0.05$.

\section{Results}

\subsection{Soil physical and chemical properties}

Table 1 summarizes the main physical and chemical properties of the investigated soils ( $\mathrm{pH}, \mathrm{LOI}, \mathrm{SSA}$ and CEC). Soil samples were predominantly near neutral to neutral and covered a range of $\mathrm{pH}$ values from 6 to 7 . The organic matter content (LOI) was relatively high, with an average of $10.1 \%$. The highest LOI value was determined in the soil from location S2 (15.7\%), while the lowest was obtained for the soil sample from location S9 (6.8\%).

The investigated samples showed minor variations in surface physico-chemical characteristics (SSA, CEC). The SSA values were low and in the narrow range from $5.3 \mathrm{~m}^{2} \mathrm{~g}^{-1}$, in sample $S 7$, to $9.8 \mathrm{~m}^{2} \mathrm{~g}^{-1}$ determined in sample S9. The CEC values ranged from

Table 1

The $\mathrm{pH}$, loss on ignition (LOI), cation exchange capacity (CEC) and specific surface area (SSA) values of the investigated soils.

\begin{tabular}{lllll}
\hline Sample & $\mathrm{pH}$ & LOI $(\mathrm{wt} . \%)$ & CEC $(\mathrm{cmol} / \mathrm{kg})$ & $\mathrm{SSA}\left(\mathrm{m}^{2} / \mathrm{g}\right)$ \\
\hline S1 & 6.5 & 9.14 & 25.6 & 8.00 \\
S2 & 7.0 & 15.7 & 28.9 & 5.58 \\
S3 & 6.5 & 8.07 & 24.2 & 7.14 \\
S4 & 7.0 & 10.0 & 22.8 & 6.61 \\
S5 & 7.0 & 10.9 & 22.0 & 6.60 \\
S6 & 7.0 & 7.21 & 17.6 & 8.92 \\
S7 & 7.0 & 12.4 & 26.5 & 5.33 \\
S8 & 7.0 & 10.2 & 16.1 & 6.81 \\
S9 & 6.0 & 6.79 & 16.2 & 9.78 \\
S10 & 7.0 & 11.0 & 29.4 & 6.98 \\
\hline
\end{tabular}


$16 \mathrm{cmol} \mathrm{kg}^{-1}$ in samples S8-9 to the highest value of $29.4 \mathrm{cmol} \mathrm{kg}^{-1}$ determined in sample S10.

\subsection{Rare earth distribution in samples}

Results of measurement of REEs (La, Ce, Pr, Nd, Sm, Eu, Gd, Tb, Dy, Ho, Er, Tm, Yb, Lu) and Y are presented in Tables 2 and 3, along with the calculated ratios, anomalies and fractionation indices. For purpose of data interpretation, rare earth elements were divided into several groups; the light rare earths (LREE, including elements from La to Gd), the heavy rare earths (HREE, including elements from $\mathrm{Tb}$ to $\mathrm{Lu}$ ) and the middle rare earths (MREE, overlapping the first two groups and including the elements from Sm to Ho). Concentrations of REEs $+\mathrm{Y}$ in all analyzed samples ranged over four orders of magnitude, from $0.007 \mathrm{mg} \mathrm{kg}^{-1}$ (Lu) to $79.6 \mathrm{mg} \mathrm{kg}^{-1}$ (Ce), with $\Sigma$ REE ranging from $1.94 \mathrm{mg} \mathrm{kg}^{-1}$ to $191 \mathrm{mg} \mathrm{kg}^{-1}$ (Table 2). Among them, Ce was present at the highest levels in all samples, accounting between $38 \%$ and $41 \%$ of the total REE, while Tm and $\mathrm{Lu}$ exhibited the lowest values. Highest concentrations of REEs were measured in soil samples where their averaged $\Sigma$ REE value reached $181 \pm 12 \mathrm{mg} \mathrm{kg}^{-1}$, while mosses and mushrooms exhibited lower REE concentrations, with average $\Sigma$ REE values of $4.23 \pm 0.91 \mathrm{mg} \mathrm{kg}^{-1}$ and $6.17 \pm 4.10 \mathrm{mg} \mathrm{kg}^{-1}$, respectively.

In general, a lower variability of element concentrations was observed in soil samples, where RSD ranged from $6 \%$ to $11 \%$, compared to moss samples where RSD ranged from $12 \%$ to $25 \%$. In fruiting bodies of mushrooms an increase in average $\Sigma$ REE concentrations was observed from stipes to pileus $\left(8.55 \mathrm{mg} \mathrm{kg}^{-1}\right.$ to $11.1 \mathrm{mg} \mathrm{kg}^{-1}$ in $\mathrm{F}_{\mathrm{A}}$ and $1.94 \mathrm{mg} \mathrm{kg}^{-1}$ to $3.50 \mathrm{mg} \mathrm{kg}^{-1}$ in $\mathrm{F}_{\mathrm{B}}$ ). Accordingly, RSD for individual REEs ranged from $9 \%$ to $16 \%$ in $\mathrm{F}_{\mathrm{A}}$, and from $10 \%$ to $38 \%$ in $\mathrm{F}_{\mathrm{B}}$.

In all investigated samples LREEs were found to be more abundant, with average LREE/HREE ratios of 13.8, 15.5 and 13.3 for soil, moss and mushroom samples, respectively. The content of
LREEs accounted for 92.5-93.6\% of total REEs in the investigated soils, and $93.9 \%$ and $92.9 \%$ in moss and mushroom samples, respectively.

Differences in the mean values of all REEs among the studied groups (soil, mushroom and moss) were greater than expected, whereas no statistically significant difference $(\mathrm{p}<0.05$ ) was observed between samples of mosses and mushrooms The latter arises from the fact that the levels of REE in soils were significantly higher than those observed in biota samples.

\subsection{Europium and cerium anomalies}

Samples of soil exhibited a slightly positive europium anomaly $\left(\mathrm{Eu} / \mathrm{Eu}^{*}=\mathrm{Eu}_{\mathrm{NASC}} /\left(\mathrm{Sm}_{\mathrm{NASC}} \times \mathrm{Gd}_{\mathrm{NASC}}\right)^{0.5}=1.08-1.21\right)$ and a slightly negative cerium anomaly $\left(\mathrm{Ce} / \mathrm{Ce}^{*}=\mathrm{Ce}_{\mathrm{NASC}}\right.$ $\left.\left(\text { La NASC } \times \operatorname{Pr}_{\text {NASC }}\right)^{0.5}=0.89-0.96\right)$ (Table 3$)$. Both europium and cerium anomalies in soil samples were in a rather narrow range, compared to values obtained for biota samples. For mushrooms and mosses, the Eu/Eu* values (Table 3) exhibited positive to strong positive anomaly, ranging from 1.32 to 1.70 and from 1.09 to 1.73 , respectively. Nevertheless, the cerium anomaly (Table 3) displayed a narrower set of values, ranging from 0.93 to 1.08 , and from 0.99 to 1.15 for mosses and mushrooms, respectively.

\subsection{NASC-normalised patterns}

Standards which are commonly used for REE normalization include the World Shale Average (WSA), North American Shale Composite (NASC), Post Archean Australian Shale (PAAS), Upper Continental Crust (UCC), and average chondrites. Given the nature of studied samples, shale-based standards were considered most appropriate. The PAAS and NASC normalised patterns displayed similar features, and the latter was selected henceforth as the standard for normalization.

Table 2

Concentrations of REEs in soil, moss and mushroom samples, expressed in mg kg-1.

\begin{tabular}{|c|c|c|c|c|c|c|c|c|c|c|c|c|c|c|c|c|}
\hline & $\mathrm{Y}$ & $\mathrm{La}$ & $\mathrm{Ce}$ & $\mathrm{Pr}$ & $\mathrm{Nd}$ & $\mathrm{Sm}$ & $\mathrm{Eu}$ & Gd & $\mathrm{Tb}$ & Dy & Ho & $\mathrm{Er}$ & $\mathrm{Tm}$ & $\mathrm{Yb}$ & Lu & $\Sigma$ REE \\
\hline \multicolumn{17}{|l|}{ Soils } \\
\hline S1 & 25.1 & 37.5 & 74.3 & 9.6 & 36.3 & 7.28 & 1.77 & 5.77 & 1.02 & 5.04 & 1.09 & 2.88 & 0.468 & 2.70 & 0.485 & 186 \\
\hline S2 & 27.0 & 38.0 & 73.3 & 9.5 & 37.1 & 7.80 & 1.68 & 6.09 & 1.02 & 5.25 & 1.14 & 2.96 & 0.505 & 2.69 & 0.477 & 188 \\
\hline S3 & 22.3 & 37.6 & 75.0 & 9.5 & 35.6 & 7.06 & 1.69 & 5.92 & 0.938 & 4.56 & 0.917 & 2.50 & 0.438 & 2.35 & 0.458 & 185 \\
\hline S4 & 23.1 & 35.8 & 72.7 & 9.2 & 34.6 & 7.31 & 1.70 & 5.54 & 0.909 & 4.60 & 0.992 & 2.55 & 0.413 & 2.26 & 0.446 & 179 \\
\hline S5 & 22.8 & 36.6 & 74.0 & 9.2 & 35.0 & 7.11 & 1.62 & 5.56 & 0.929 & 4.57 & 0.979 & 2.52 & 0.437 & 2.41 & 0.444 & 181 \\
\hline S6 & 22.8 & 37.4 & 76.4 & 9.5 & 36.3 & 7.61 & 1.62 & 5.42 & 0.978 & 4.74 & 1.04 & 2.50 & 0.431 & 2.49 & 0.450 & 187 \\
\hline S7 & 18.3 & 30.7 & 63.5 & 7.7 & 28.6 & 5.83 & 1.36 & 4.54 & 0.778 & 3.68 & 0.810 & 2.09 & 0.357 & 2.07 & 0.357 & 153 \\
\hline S8 & 20.7 & 36.6 & 74.1 & 9.1 & 33.4 & 6.68 & 1.52 & 5.41 & 0.847 & 4.14 & 0.899 & 2.29 & 0.423 & 2.36 & 0.406 & 178 \\
\hline S9 & 22.3 & 36.8 & 76.7 & 9.3 & 36.4 & 7.00 & 1.60 & 5.72 & 0.931 & 4.60 & 0.950 & 2.38 & 0.428 & 2.40 & 0.447 & 186 \\
\hline S10 & 23.2 & 38.7 & 79.6 & 9.7 & 36.5 & 7.39 & 1.66 & 5.65 & 0.936 & 4.50 & 0.975 & 2.50 & 0.468 & 2.38 & 0.468 & 191 \\
\hline \multicolumn{17}{|c|}{ Mosses } \\
\hline M1 & 0.407 & 0.733 & 1.44 & 0.175 & 0.655 & 0.117 & 0.044 & 0.114 & 0.020 & 0.082 & 0.019 & 0.042 & 0.010 & 0.038 & 0.010 & 3.50 \\
\hline M2 & 0.346 & 1.03 & 2.61 & 0.308 & 1.17 & 0.228 & 0.055 & 0.152 & 0.030 & 0.132 & 0.029 & 0.074 & 0.013 & 0.062 & 0.013 & 5.90 \\
\hline M3 & 0.445 & 0.898 & 1.82 & 0.209 & 0.789 & 0.146 & 0.043 & 0.112 & 0.023 & 0.093 & 0.020 & 0.047 & 0.010 & 0.047 & 0.010 & 4.27 \\
\hline M4 & 0.381 & 0.687 & 1.49 & 0.176 & 0.643 & 0.129 & 0.038 & 0.116 & 0.021 & 0.081 & 0.019 & 0.045 & 0.009 & 0.039 & 0.009 & 3.50 \\
\hline M5 & 0.487 & 0.977 & 1.91 & 0.223 & 0.834 & 0.163 & 0.048 & 0.117 & 0.023 & 0.094 & 0.022 & 0.050 & 0.011 & 0.045 & 0.011 & 4.52 \\
\hline M6 & 0.512 & 1.11 & 2.42 & 0.272 & 1.01 & 0.196 & 0.053 & 0.138 & 0.028 & 0.114 & 0.027 & 0.059 & 0.013 & 0.052 & 0.013 & 5.51 \\
\hline M7 & 0.395 & 0.649 & 1.29 & 0.148 & 0.562 & 0.110 & 0.038 & 0.094 & 0.020 & 0.071 & 0.019 & 0.040 & 0.010 & 0.034 & 0.010 & 3.09 \\
\hline M8 & 0.542 & 0.807 & 1.58 & 0.190 & 0.725 & 0.138 & 0.041 & 0.121 & 0.024 & 0.098 & 0.023 & 0.058 & 0.010 & 0.049 & 0.011 & 3.87 \\
\hline M9 & 0.484 & 0.968 & 1.92 & 0.232 & 0.827 & 0.163 & 0.046 & 0.138 & 0.025 & 0.093 & 0.021 & 0.048 & 0.010 & 0.041 & 0.011 & 4.54 \\
\hline M10 & 0.422 & 0.777 & 1.51 & 0.177 & 0.661 & 0.123 & 0.039 & 0.100 & 0.021 & 0.084 & 0.019 & 0.043 & 0.010 & 0.035 & 0.010 & 3.61 \\
\hline \multicolumn{17}{|c|}{ Mushrooms } \\
\hline $\mathrm{F}_{\mathrm{A}} 1$ & 0.588 & 1.15 & 3.60 & 0.461 & 1.88 & 0.422 & 0.088 & 0.267 & 0.049 & 0.261 & 0.054 & 0.145 & 0.024 & 0.135 & 0.024 & 8.55 \\
\hline $\mathrm{F}_{\mathrm{A}} 2$ & 0.704 & 1.58 & 4.74 & 0.596 & 2.40 & 0.503 & 0.110 & 0.313 & 0.061 & 0.295 & 0.064 & 0.171 & 0.029 & 0.162 & 0.029 & 11.0 \\
\hline $\mathrm{F}_{\mathrm{A}} 3$ & 0.786 & 1.39 & 4.07 & 0.522 & 2.13 & 0.476 & 0.098 & 0.335 & 0.060 & 0.300 & 0.069 & 0.174 & 0.029 & 0.153 & 0.028 & 9.84 \\
\hline $\mathrm{F}_{\mathrm{B}} 1$ & 0.208 & 0.388 & 0.818 & 0.094 & 0.364 & 0.063 & 0.025 & 0.065 & 0.014 & 0.045 & 0.011 & 0.022 & 0.008 & 0.018 & 0.007 & 1.94 \\
\hline $\mathrm{F}_{\mathrm{B}} 2$ & 0.254 & 0.426 & 0.899 & 0.103 & 0.417 & 0.071 & 0.026 & 0.069 & 0.014 & 0.053 & 0.013 & 0.026 & 0.009 & 0.022 & 0.009 & 2.16 \\
\hline $\mathrm{F}_{\mathrm{B}} 3$ & 0.355 & 0.734 & 1.47 & 0.177 & 0.639 & 0.123 & 0.036 & 0.107 & 0.022 & 0.068 & 0.019 & 0.040 & 0.009 & 0.037 & 0.009 & 3.50 \\
\hline
\end{tabular}

\footnotetext{
${ }^{\text {a }}$ Note: $\mathrm{F}_{\mathrm{A}}$ and $\mathrm{F}_{\mathrm{B}}$ were collected at the same locations as $\mathrm{S} 2$ and $\mathrm{S} 3$, respectively.
} 
Table 3

Calculated ratios, anomalies and fractionation indices for the studied samples.

\begin{tabular}{|c|c|c|c|c|c|c|c|c|}
\hline & $\Sigma$ LREE/ $/$ HREE & $\Sigma$ MREE/ $\Sigma$ REE & $\Sigma$ LREE $_{\text {NASC }} / \Sigma$ HREE $_{\text {NASC }}$ & $\Sigma \mathrm{MREE}_{\text {NASC }} / \Sigma \mathrm{REE}_{\mathrm{NASC}}$ & $\mathrm{Eu} / \mathrm{Eu}^{*}$ & $\mathrm{Ce} / \mathrm{Ce}^{*}$ & $(\mathrm{La} / \mathrm{Yb})_{\text {NASC }}$ & $(\mathrm{Nd} / \mathrm{Yb})_{\mathrm{NASC}}$ \\
\hline \multicolumn{9}{|l|}{ Soils } \\
\hline S1 & 12.6 & 0.46 & 1.20 & 0.46 & 1.21 & 0.91 & 1.36 & 1.50 \\
\hline S2 & 12.4 & 0.46 & 1.18 & 0.46 & 1.08 & 0.89 & 1.39 & 1.54 \\
\hline S3 & 14.2 & 0.45 & 1.32 & 0.45 & 1.16 & 0.92 & 1.57 & 1.69 \\
\hline S4 & 13.7 & 0.46 & 1.30 & 0.46 & 1.19 & 0.93 & 1.55 & 1.71 \\
\hline S5 & 13.8 & 0.46 & 1.28 & 0.45 & 1.15 & 0.93 & 1.49 & 1.62 \\
\hline S6 & 14.0 & 0.45 & 1.27 & 0.46 & 1.12 & 0.94 & 1.48 & 1.63 \\
\hline S7 & 14.7 & 0.45 & 1.29 & 0.45 & 1.17 & 0.96 & 1.46 & 1.54 \\
\hline S8 & 14.3 & 0.45 & 1.33 & 0.45 & 1.12 & 0.94 & 1.52 & 1.58 \\
\hline S9 & 14.7 & 0.45 & 1.31 & 0.45 & 1.12 & 0.96 & 1.51 & 1.69 \\
\hline S10 & 12.6 & 0.46 & 1.31 & 0.45 & 1.14 & 0.95 & 1.60 & 1.71 \\
\hline \multicolumn{9}{|c|}{ Mosses } \\
\hline M1 & 14.8 & 0.47 & 1.32 & 0.47 & 1.70 & 0.93 & 1.90 & 1.92 \\
\hline M2 & 15.7 & 0.45 & 1.38 & 0.45 & 1.32 & 1.08 & 1.63 & 2.11 \\
\hline M3 & 16.0 & 0.45 & 1.36 & 0.45 & 1.48 & 0.97 & 1.86 & 1.86 \\
\hline M4 & 14.6 & 0.47 & 1.29 & 0.47 & 1.37 & 1.00 & 1.72 & 1.82 \\
\hline M5 & 16.6 & 0.46 & 1.42 & 0.46 & 1.53 & 0.95 & 2.14 & 2.07 \\
\hline M6 & 17.0 & 0.45 & 1.40 & 0.45 & 1.44 & 1.02 & 2.09 & 2.16 \\
\hline M7 & 14.1 & 0.47 & 1.19 & 0.47 & 1.66 & 0.96 & 1.88 & 1.85 \\
\hline M8 & 13.2 & 0.46 & 1.18 & 0.46 & 1.40 & 0.93 & 1.63 & 1.67 \\
\hline M9 & 17.2 & 0.46 & 1.46 & 0.46 & 1.35 & 0.94 & 2.30 & 2.23 \\
\hline M10 & 15.3 & 0.46 & 1.29 & 0.46 & 1.57 & 0.94 & 2.21 & 2.13 \\
\hline \multicolumn{9}{|c|}{ Mushrooms $^{\mathrm{a}}$} \\
\hline $\mathrm{F}_{\mathrm{A}} 1$ & 11.4 & 0.48 & 1.15 & 0.48 & 1.16 & 1.15 & 0.84 & 1.56 \\
\hline $\mathrm{F}_{\mathrm{A}} 2$ & 12.6 & 0.46 & 1.21 & 0.46 & 1.23 & 1.14 & 0.96 & 1.66 \\
\hline $\mathrm{F}_{\mathrm{A}} 3$ & 11.1 & 0.48 & 1.09 & 0.48 & 1.09 & 1.11 & 0.90 & 1.56 \\
\hline $\mathrm{F}_{\mathrm{B}} 1$ & 14.6 & 0.47 & 1.16 & 0.47 & 1.73 & 0.99 & 2.12 & 2.26 \\
\hline $\mathrm{F}_{\mathrm{B}} 2$ & 13.8 & 0.46 & 1.09 & 0.46 & 1.63 & 1.00 & 1.91 & 2.12 \\
\hline $\mathrm{F}_{\mathrm{B}} 3$ & 16.1 & 0.46 & 1.31 & 0.46 & 1.38 & 0.95 & 1.97 & 1.94 \\
\hline
\end{tabular}

$\mathrm{Eu} / \mathrm{Eu}^{*}$ - europium anomaly $\left(\mathrm{Eu} / \mathrm{Eu}^{*}=\mathrm{Eu}_{\mathrm{NASC}} /\left(\mathrm{Sm}_{\mathrm{NASC}} \times \mathrm{Gd}_{\mathrm{NASC}}\right)^{0.5}\right)$.

$\mathrm{Ce} / \mathrm{Ce}^{*}$ - cerium anomaly $\left(\mathrm{Ce} / \mathrm{Ce}^{*}=\mathrm{Ce}_{\text {NASC }} /\left(\operatorname{La}_{\text {NASC }} \times \operatorname{Pr}_{\text {NASC }}\right)^{0.5}\right)$.

${ }^{a}$ Note: $F_{A}$ and $F_{B}$ were collected at the same locations $S 2$ and $S 3$, respectively.

The average REE patterns normalised with respect to the estimated average composition of NASC (Gromet et al., 1984) are presented in Fig. 2.

Although the normalised patterns of soil samples were similar, they displayed certain variability in the LREE part, resulting in a flat to concave shape of the normalised curve (Fig. 2a). The latter is clearly distinguishable in moss samples as well (Fig. 2a); while the normalised patterns of mushrooms have the appearance of two end members of the above-mentioned variability (Fig. 2b).

\subsection{NASC-normalised ratios}

The REE normalised ratios of soil samples were characterised by

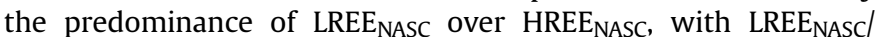
HREE $_{\text {NASC }}$ ranging from 1.18 to 1.33 , ( $\left.\mathrm{La} / \mathrm{Yb}\right)_{\text {NASC }}$ ranging from 1.36 to 1.60 , and $(\mathrm{Nd} / \mathrm{Yb})_{\text {NASC }}$ ranging from 1.50 to 1.71 (Table 3$)$. The predominance of light REEs in mosses was even more pronounced, as reflected in higher values of $\mathrm{LREE}_{\mathrm{NASC}} / \mathrm{HREE}_{\mathrm{NASC}},(\mathrm{La} / \mathrm{Yb})_{\mathrm{NASC}}$ and $(\mathrm{Nd} / \mathrm{Yb})_{\text {NASC }}$ ratios:, ranging from 1.18 to $1.46,1.63$ to 2.30 , and 1.67 to 2.23 , respectively (Table 3 ). Interestingly, the mushroom samples showed significantly different values of these parameters, with the following range of LREE $_{\text {NASC }} / \mathrm{HREE}_{\mathrm{NASC}},(\mathrm{La} / \mathrm{Yb})_{\mathrm{NASC}}$ and $(\mathrm{Nd} /$ Yb) NASC $_{\text {: }} 1.09$ to $1.21,0.84$ to 0.96 and 1.56 to 1.66 , respectively, in samples $\mathrm{F}_{\mathrm{A}}$, and 1.09 to $1.31,1.91$ to 2.12 and 1.94 to 2.26 , respectively, in samples $F_{B}$ (Table 3).

\section{Discussion}

\subsection{Soil properties}

Since the lanthanides in mosses originate mostly from windblown particles, which are, at least partly, influenced by the local pedological and geological background, it is necessary to consider the characteristics of the local substrate and its main features $(\mathrm{pH}$, organic matter content, CEC, SSA, etc.) when investigating the uptake of REEs. Soil organic matter (OM) has numerous negatively charged groups and, thereby, a high capacity to adsorb or chelate divalent and trivalent cations (Wu et al., 2001; Tyler, 2004), such as REEs, thus influencing their mobility. The positive correlation found between LOI (\%) and CEC (c.c. 0.67; p < 0.05) and the negative correlation between LOI (\%) and SSA (c.c. - 0.85; p < 0.05) suggests that in the studied soils organic matter is mostly responsible for the exchange of cations with the surroundings.

While the content of organic matter controls the REE bioavailability as chelating and adsorbing agent (Dołegowska and Migaszewski, 2013), pH, on the other hand, plays an important role in the stability of REE complexes. According to Cao et al. (2001) and Tyler and Olsson (2001) bond strengths of the REE-organic complexes become greater with increasing soil $\mathrm{pH}$. In general, at pHs below 6, metal-organic complexes, which are mostly negatively charged, readily adsorb onto soil particles, while at $\mathrm{pH}>6$ or 7 , they become more soluble, releasing the metals in the soil solution (Tack, 2010). Thus, at near neutral pHs, as found in the studied soils (Table 1 ), it is reasonable to expect a certain amount of the bioavailable fraction of REEs.

\subsection{Rare earths in soil}

The average concentrations of $\Sigma$ REE in soil samples (181 $\mathrm{mg} \mathrm{kg}^{-1}$ ) were in agreement with the values reported by Fiket et al. (2016) for Croatian soils (191 $\mathrm{mg} \mathrm{kg}^{-1}$ ). Although slightly below the world average (194 $\mathrm{mg} \mathrm{kg}^{-1}$, Wang et al., 1989), the levels of individual REEs in the analyzed soils correspond to the medium level range of REE in the European soils (Fedele et al., 2008).

In general, LREE showed substantial predominance over HREE (Table 3), which is typical for soils developed on sedimentary and 


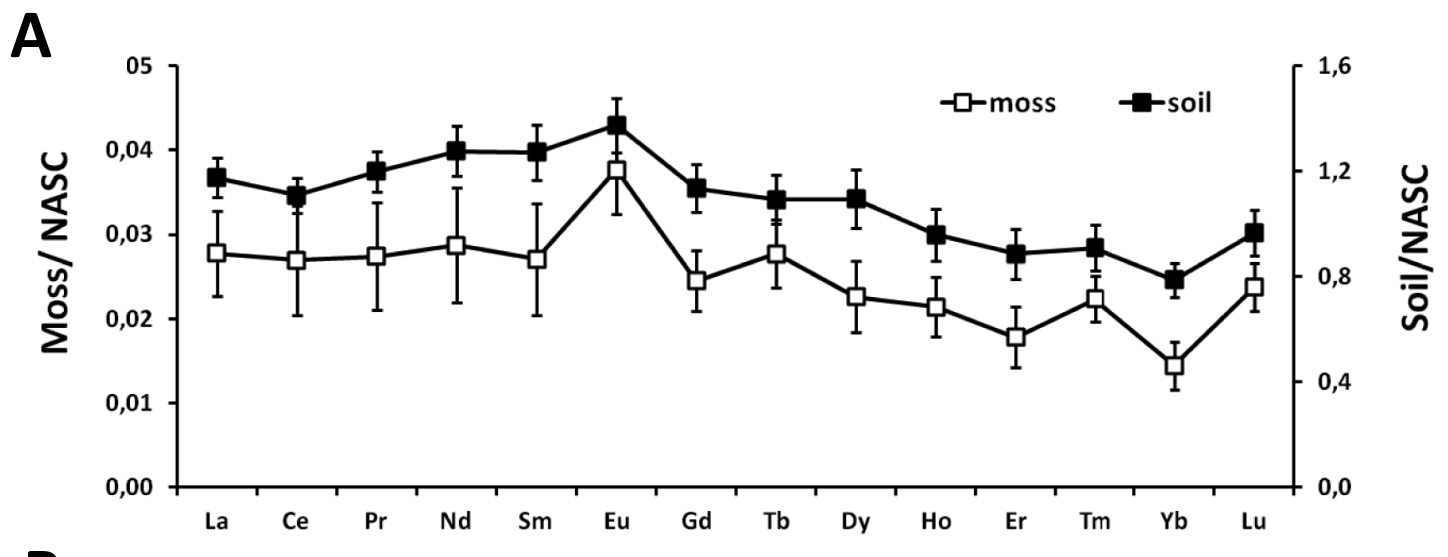

B

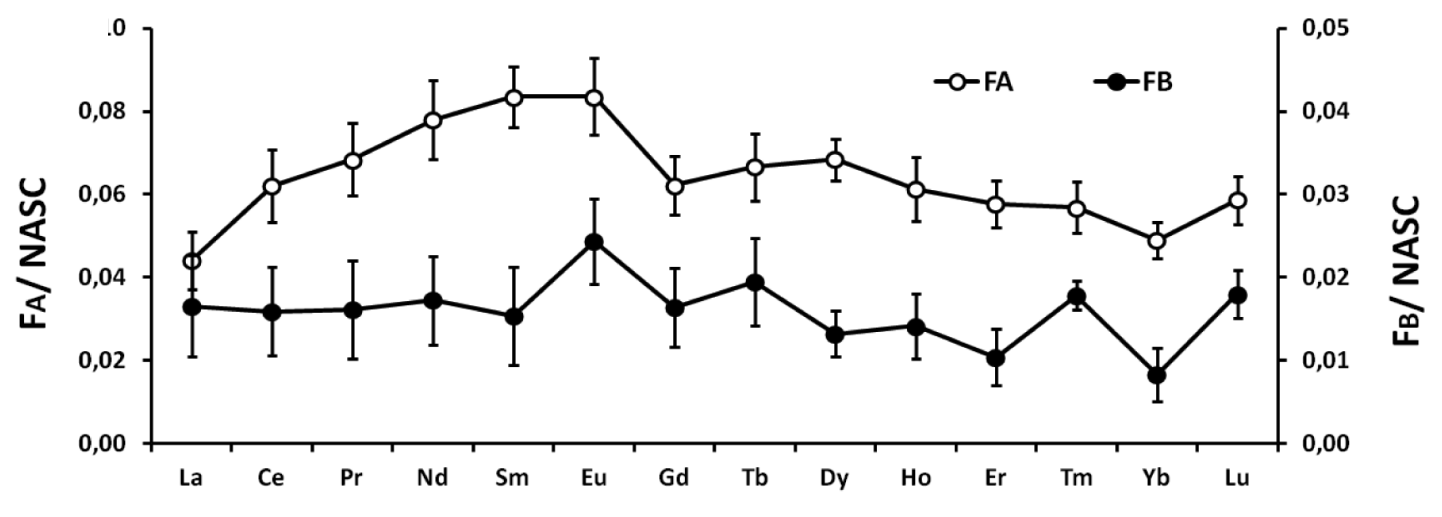

Element

Fig. 2. NASC-normalised REE patterns of a) moss and soil samples; b) mushroom samples.

carbonate rocks (Chen and Yang, 2010; Dołegowska and Migaszewski, 2013). Nevertheless, the obtained average LREE/ HREE ratio (13.8 $\mathrm{mg} \mathrm{kg}^{-1}$ ) was lower compared to the topsoil of a relatively pristine forest of the Kielce area $\left(25.1 \mathrm{mg} \mathrm{kg}^{-1}\right.$, Dołegowska and Migaszewski, 2013).

However, contrary to the measured REE concentrations, the NASC-normalised patterns revealed only a slight predominance of

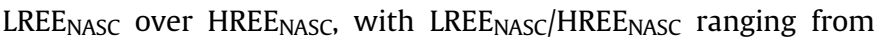
1.18 to 1.33 (Table 3), which is in accordance with the data from Dołegowska and Migaszewski (2013). Analogously to their findings, the highest enrichment of REE normalised values was evident for medium rare earths, i.e. elements from $\mathrm{Sm}$ to Ho, as reflected in positive $(\mathrm{Nd} / \mathrm{Yb})_{\mathrm{NASC}}$ ratios, with an average value of 1.62 , and $(\mathrm{Nd} /$ $\mathrm{Yb})_{\text {NASC }}>(\mathrm{La} / \mathrm{Yb})_{\text {NASC }}$.

\subsection{Rare earths in mosses}

The role of particle deposition is less important in vascular than in the non-vascular plants where mineral particles are a source of many metals (Dołegowska and Migaszewski, 2013). Mosses, as nonvascular plants without proper roots, take up most elements directly from precipitation and dry deposition (rainfall, stem flow, dust) (Dołegowska and Migaszewski, 2013), wherein soil or airborne particles deposited on a moss surface may be partly dissolved and assimilated. In the case of epiphytic mosses, i.e. those growing on trees, previous findings suggest that the incoming flux of trace elements from the atmosphere, wet or dry deposition, could be substantially modified by the canopy before reaching the moss, and that the trace elements supplied to the tree through the root system and eventually leached out, contribute to the element concentration in the moss (Berg and Steinnes, 1997). Since the study area is a pristine forest, the dominant contribution to element levels in studied moss samples could be expected from the particles, primarily reflecting the local soil composition and the overall tree uptake.

The average concentrations of $\Sigma$ REEs in moss samples (4.23 $\mathrm{mg} \mathrm{kg}^{-1}$ ) were higher than those reported by Rühling and Tyler (2004) (0.98 $\mathrm{mg} \mathrm{\textrm {kg } ^ { - 1 }}$ ), Berg and Steinnes (1997) (1.31 $\left.\mathrm{mg} \mathrm{kg}^{-1}\right)$ Castorina and Masi (2015) (1.36 mg kg-1), Tyler (2004) (1.36 mg kg-1), Vuković et al. (2015) (2.24 mg kg-1) and Dołegowska and Migaszewski (2013) (3.73 $\mathrm{mg} \mathrm{kg}^{-1}$ ), but lower than the ones recorded by Chiarenzelli et al. (2001) (12.1 $\mathrm{mg} \mathrm{kg}^{-1}$ ). Since among the reported values are those derived from studies where the impact of anthropogenic activities on the level of REEs was investigated (Rühling and Tyler, 2004), a wide range of values could be explained by diverse anthropogenic influences (fertilizers, dust) and by differences in lithological or geological settings of the studied areas.

The concentrations of REEs in mosses followed the same order as in soil samples, $\mathrm{Ce}>\mathrm{La}>\mathrm{Nd}>\mathrm{Y}>\mathrm{Pr}>\mathrm{Sm}>\mathrm{Gd}>\mathrm{Dy}>\mathrm{Er}>\mathrm{Eu}$, $\mathrm{Yb}>\mathrm{Ho}, \mathrm{Tb}>\mathrm{Lu}, \mathrm{Tm}$, and coincided with the order reported by Dołegowska and Migaszewski (2013), with the exception of Eu. The observed similarity in REE distribution between mosses and soils suggests their common geogenic source, while the elevated Eu levels indicate a certain degree of fractionation, confirmed by higher values of the Eu anomaly in mosses than in soil.

The characteristic predominance of light over heavy rare earth elements (LREE/HREE average $=15.5$ ) was somewhat more 
pronounced than in the north European (8.33, Dołegowska and Migaszewski, 2013; 8.51, Berg and Steinnes, 1997; and 11.64, Rühling and Tyler, 2004). The average LREE/HREE ratio in studied mosses showed most similarity to the Canadian mosses (12.61, Chiarenzelli et al., 2001) and the values obtained for the local soils $\left(\mathrm{LREE}_{\mathrm{HREE}} \mathrm{Hverage}_{\mathrm{a}}=13.8\right)$. The latter was also evident in the shape of the normalised curves, except for Eu (Fig. 2a). All of the above points to the predominant influence of the forest environment on the REE fingerprint in the studied mosses, which is not surprising given the pristine conditions of the study area and the absence of major anthropogenic pressures.

To additionally clarify the conditions of accumulation of REEs in mosses, the accumulation ratio (AR) (Chopin et al., 2008) was calculated as a ratio of element concentration in the moss sample to its total concentration in the soil according to the equation: $\mathrm{AR}=\mathrm{C}_{\text {moss }} / \mathrm{C}_{\text {soil }}$. In order to reveal the influence of soil properties and REE concentration on the fractionation of REE by mosses, AR was calculated for REEs, LREEs, MREEs and HREEs. For all REEs including $Y$, the $A R_{R E E}$ values suggest slight accumulation $\left(\mathrm{AR}=10^{-2}-10^{-1}\right)$, ranging from 0.018 to 0.027 , with an average RSD of $17 \%$. The highest average AR value was observed for Eu. Nevertheless, similar values of the average $A_{\text {LREE, }} A_{\text {MREE, }}$ and $\mathrm{AR}_{\text {HREE}}$, i.e. amounting to $0.23,0.22$ and 0.21 , respectively, suggest lack of significant fractionation during the intake of REEs by mosses.

\subsection{Rare earths in mushrooms}

The average REE total in mushroom samples $\left(6.17 \mathrm{mg} \mathrm{kg}^{-1}\right)$ was higher than those reported for the ectomycorrhizal and saprobic macro fungi (up to $0.36 \mathrm{mg} \mathrm{kg}^{-1}$ ) (Borovička et al., 2011) and the above-ground mushroom species $\left(1.39 \mathrm{mg} \mathrm{kg}^{-1}\right.$ ) (Mleczek et al., 2015). The obtained levels of rare earths in mushrooms were also higher compared to the data reported for ectomycorrhizal fungi by Aruguete et al. (1998) (up to $0.204 \mathrm{mg} \mathrm{kg}^{-1}$ for La, $1.03 \mathrm{mg} \mathrm{kg}^{-1}$ for Ce and $0.025 \mathrm{mg} \mathrm{kg}^{-1}$ for $\mathrm{Nd}$ ). Nevertheless, the values obtained for $\mathrm{Nd}$ were lower than those determined in mushrooms from the Iberian Peninsula, Spain (Nd: 2.8-7.1 mg kg-1) (Campos et al., 2009). Wide ranges of concentrations reported in the literature for REEs in mushrooms of unpolluted areas were sometimes interpreted as false, or in the case of high values in mushrooms from the Iberian Peninsula (Campos et al., 2009), as excessive and erroneous (Borovička et al., 2011). However, according to European geochemical maps (Salminen et al., 2005) and the available data (Amorós Ortiz-Villajos et al., 2011), several locations on the Iberian Peninsula, including the area encompassed by the study of Campos et al. (2009), contain elevated levels of REEs, which could explain higher concentrations found in biota. Accordingly, overall higher levels of REEs in mushrooms and mosses of the Prašnik area could be attributed primarily to the local pedological setting and the naturally present higher levels of rare earths in soil.

The REE concentrations in mushrooms followed the same order as in soil and moss samples, along with the Eu anomaly, mimicking the distribution observed in soil. As in mosses, the average LREE/ HREE ratios in mushrooms (LREE/HREE average $=13.3$ ) were similar to those obtained for soils $\left(\mathrm{LREE} / \mathrm{HREE}_{\text {average }}=13.8\right)$. Furthermore, all NASC normalised patterns for biota samples showed, similarly to soil samples, a slight enrichment in MREEs (Sm through Ho). The normalised MREE/ $\Sigma$ REE ratio was 0.45 for soils, 0.46 for mosses and 0.47 for mushroom samples, and in accordance with the values reported by Castorina and Masi (2015) for Romagna's mosses. Higher concentrations of MREEs in the studied topsoil, moss and mushroom samples could be attributed to the complexation of REEs by phosphate and organic ligands (Johannesson et al., 1996; Semhi et al., 2009).
Bioaccumulation capabilities of mushrooms are known to be strongly species dependent (Kalač and Svoboda, 2000; Kalač, 2010 and references therein), but also vary between different parts of the fruiting body (Dilna Damodaran et al., 2011). In the studied mushrooms, the lowest levels of REE were found in stipes, which is consistent with their function as transport, rather than storage systems. Interestingly, the increase in $\mathrm{R}$ REE from lower stipes to pileus significantly differed between samples, from $23 \%$ in $\mathrm{F}_{\mathrm{A}}$ to $44 \%$ in $\mathrm{F}_{\mathrm{B}}$. Moreover, mushroom from location $\mathrm{F}_{\mathrm{A}}$ contained up to three times higher concentrations of REEs than mushroom from location $F_{B}$. As for mosses, the index of accumulation (AR) (Chopin et al., 2008) was calculated for all REEs in mushrooms ( $A R=C_{\text {mushroom }} /$ $\mathrm{C}_{\text {soil }}$ ). The obtained $\mathrm{AR}_{\mathrm{REE}}$ values suggest slight accumulation $\left(\mathrm{AR}=10^{-2}-10^{-1}\right)$ in both mushroom samples, regardless of the part of fruiting body. For mushroom from location $F_{A}$, the AR values ranged from 0.026 to 0.060 and were 2-3 times higher than in mushroom from location $\mathrm{F}_{\mathrm{B}}(0.011-0.020)$. Despite the difference in $A R$ values between these two mushrooms, the average $A R_{L R E E}$, $A R_{M R E E}$, and $A R_{H R E E}$ values were similar within the sample group, amounting to $0.52,0.55$ and 0.55 , respectively, in mushroom $\mathrm{F}_{\mathrm{A}}$; and $0.14,0.13$ and 0.13 , respectively, in mushroom $F_{B}$. The low discrepancy of AR values within the same group of samples indicates absence of fractionation during transport between different parts of the fruiting body. Contrarily, a large discrepancy between levels of REEs in mushrooms at a distance of only several meters suggests additional influences on REEs intake.

In general, the bioaccumulation of heavy metals in macro fungi can be affected by various environmental factors, i.e. humus, $\mathrm{pH}$, metal concentration, etc. (Srivastava and Takur, 2006; Sesli et al., 2008; Falandysz et al., 2007). In soils sampled at same locations as mushrooms, no difference in values of $\Sigma$ REE, SSA, CEC and $\mathrm{pH}$ was observed. However, a substantial difference was observed in the organic matter content of these two soils, $15.7 \%$ LOI at $F_{A}$ (location S2) and 8.1\% LOI at $F_{B}$ (location S3). This suggests a strong influence of organic matter content in soil on REEs mobility and availability in mushrooms.

While the observed REE fractionation in mushrooms was negligible, the intensity of bioaccumulation was found to be strongly influenced by local soil characteristics (organic matter content, etc.). Even though samples are of a limited number, provided data serve as an indication of the impact of soil organic matter on the distribution of REEs in mushrooms. All of the above further underline the necessity of taking into account local pedological and geological characteristics in order to provide a correct interpretation of levels of REEs in biota, rather than one based solely on the comparison of types and species of biological samples.

\subsection{Fractionation of rare earths between soil and biota}

In both mosses and mushrooms, levels of REEs were found to be 2-3 orders of magnitude lower than in soil, which is consistent with the literature data (Chiarenzelli et al., 2001). Nevertheless, contrary to Chiarenzelli et al. (2001), the REE patterns in mosses and mushrooms did not significantly differ from the immediate subjacent substrate. Moreover, the normalised patterns were found to be different from NASC, resulting in a non-flat pattern.

To further investigate the fractionation of rare earths between soil and biota (mosses and mushrooms), the REE ratios ((La/Yb) NASC vs. $(\mathrm{Nd} / \mathrm{Yb})_{\text {NASC }}$ and LREE $\mathrm{NASC}_{\mathrm{HREE}} \mathrm{HASC}_{\mathrm{NS}}$. Eu/Eu*) were used. The combination of $(\mathrm{La} / \mathrm{Yb})_{\text {NASC }}$ and $(\mathrm{Nd} / \mathrm{Yb})_{\text {NASC }}$ ratios allowed a clear discrimination between soil and biota samples (Fig. 3a). For all mosses as well as mushroom $F_{B}$, an increase in both of these ratios compared to soil samples was evident, pointing to a greater assimilation of LREEs and especially MREEs compared to HREEs in biota. Contrarily, mushroom $\mathrm{F}_{\mathrm{A}}$ displayed a decrease in $(\mathrm{La} / \mathrm{Yb})_{\mathrm{NASC}}$ 
A
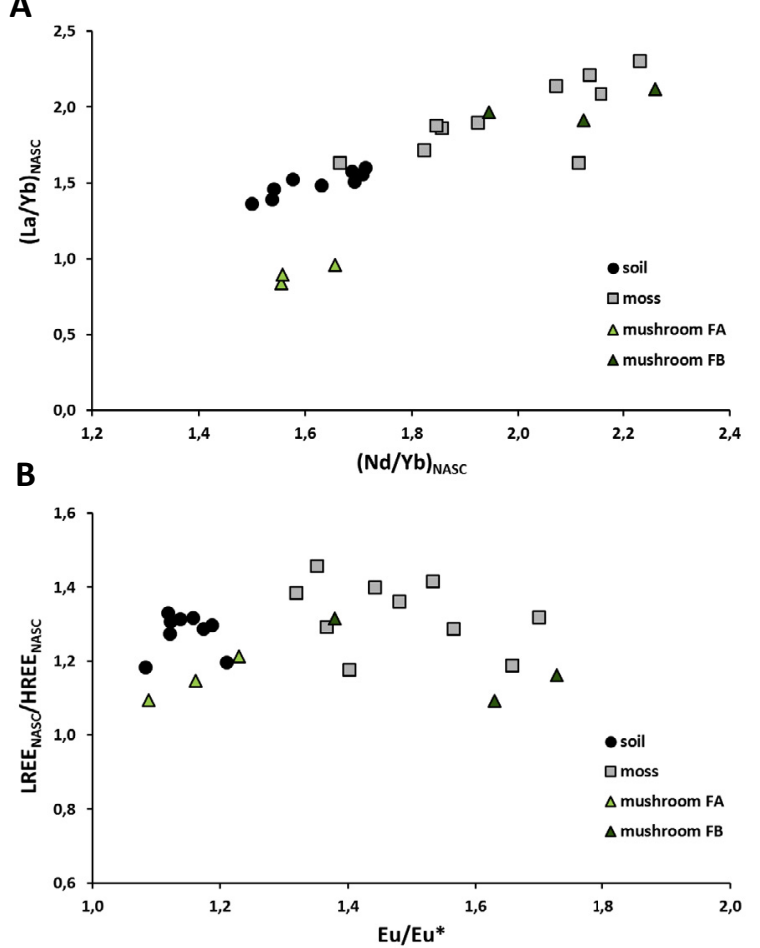

Fig. 3. Scatter plot of the following REE ratios: a) $(\mathrm{Nd} / \mathrm{Yb})_{\mathrm{NASC}} \mathrm{VS}(\mathrm{La} / \mathrm{Yb})_{\mathrm{NASC}}$, b) $\mathrm{Eu} / \mathrm{Eu}^{*}$ vs LREE $_{\text {NASC }} /$ HREE $_{\text {NASC }}$ ) obtained for studied samples.

values compared to soils, while overlapping with regard to the $(\mathrm{Nd} /$ $\mathrm{Yb})_{\text {NASC }}$ values (Fig. 3a). The observed discrepancy in (La/Yb) NASC values obtained for $F_{A}$ and $F_{B}$ suggest differences in a fractionation of particular REEs during mushroom uptake.

From the LREE $_{\text {NASC }} /$ HREE $_{\text {NASC }}$ vs. Eu/Eu* plot, a clear distinction between soil and biota samples was evident with regards to $\mathrm{Eu} / \mathrm{Eu}^{*}$ values, while LREE $_{\text {NASC}} /$ HREE $_{\text {NASC }}$ displayed lower scattering of values. Mosses and mushroom $F_{B}$ displayed an increase in the intensity of europium anomaly compared to soils, and mushroom $\mathrm{F}_{\mathrm{A}}$ (Fig. 3b). The positive Eu anomaly was also noted in the mosses from Norway (Berg and Steinnes, 1997), Sweden (Rühling and Tyler, 2004), Poland (Dołegowska and Migaszewski, 2013) and Serbia (Vuković et al., 2015), while mosses from Canada showed both Ce and Eu positive anomaly (Chiarenzelli et al., 2001). According to Dołegowska and Migaszewski (2013), the strength of the Eu anomaly in mosses is considered to be dependent on the species, its accumulative properties as well as diverse ability of trapping mineral and airborne dust particles.

In mushrooms, higher levels of $\mathrm{Sm}$ in $\mathrm{F}_{\mathrm{A}}$ created a faulty perception of lower europium anomaly compared to $\mathrm{F}_{\mathrm{B}}$. Although the convex shape of the $F_{A}$ normalised curve (Fig. 2b) suggests an increase of other LREE elements except Sm, lower $(\mathrm{Nd} / \mathrm{Yb})_{\text {NASC }}$ values could be contributed to a relative increase of $\mathrm{Yb}$ in these samples. Pourret et al. (2010) experimentally demonstrated that the distribution coefficients (Kd) between REE and humic acid (HA), one of the main forms of organic matter in soil, increased for MREE at a $\mathrm{pH} \leq 7$ and high $\mathrm{REE}$ concentrations with respect to HA. In the case of low REE concentration with respect to HA, normalised patterns exhibited HREE enrichment, the observation further confirmed by Sonke and Salters (2006) and Stern et al. (2007). Following the above, the observed differences in REE fractionation in mushrooms could presumably be explained by the difference in the content of organic matter in the soil. Unfortunately, limited data set preclude further discussion, requiring additional research on this topic.

\section{Conclusion}

This study provides baseline data on the rare earth element levels in mosses and mushrooms grown in a pristine forest area characterised by naturally elevated REE levels in the soil. In such an environment, the distribution of REEs in mosses and mushrooms was found primarily affected by local pedological setting. Overall higher levels of REEs in mushrooms and mosses of the Prašnik area were attributed to the naturally present higher levels of rare earths in soil. Moreover, despite the natural difference in the level of REEs between soils and mosses and mushrooms, obtained fractionation patterns displayed similar features characterised by positive Eu anomaly, predominance of light over heavy rare earths, with the highest enrichment for the medium rare earths. Mosses showed consistent lithological signature with almost insignificant REE fractionation compared to soils. The calculated accumulation ratios suggested a slight accumulation of REEs in both mosses and mushrooms. However, mushrooms showed differences in rare earth levels in different parts of the fruiting body with regard to their main physiological function, manifested in an increase from lower stipes to pileus. Substrate characteristics were found to influence not only the initial levels of REEs in mushrooms, but also the accumulation itself. Namely, the intensity of REE accumulation was found to be positively correlated to the soil organic content. Given mushrooms ability for metal accumulation and their application in bio-remediation studies, observed increase in the uptake of REEs from the soil containing higher levels of organic matter requires further investigation. All the aforementioned emphasises the need that for correct interpretation of levels of REEs in biota local soil characteristics must be considered. Moreover, initial substrate REE levels should be taken into account when using mosses in bio-monitoring studies and for correct assessment of possible anthropogenic pressures in different environmental compartments.

\section{Acknowledgments}

Financial support from the Croatian Science Foundation through the project 7555 TRACESS is acknowledged. Thanks to Krunoslav Szabo, Mario Bošnjak, and Vesna Marjanović (the company Hrvatske Šume) for their help during the fieldwork in late August 2015.

\section{References}

Amorós Ortiz-Villajos, J.A., García Navarro, F.J., Sánchez Jiménez, C.S., Pérez de los Reyes, C., García Moreno, R., Jiménez Ballesta, R., 2011. Trace elements distribution in red soils under semiarid mediterranean environment. Int. J. Geosci. 2, 84-97. http://dx.doi.org/10.4236/ijg.2011.22009.

Aruguete, D.M. Aldstadt, J.H., Mueller, G.M. 1998. Accumulation of several heavy metals and lanthanides in mushrooms (Agaricales) from the Chicago region. Sci. Total. Environ. 224, 43-56. http://dx.doi.org/10.1016/S0048-9697(98)00319-2.

Babula, P., Adam, V., Opatrilova, R., Zehnalek, J., Havel, L., Kizek, R., 2008. Uncommon heavy metals, metalloids and their plant toxicity: a review. Environ. Chem. Lett. 6, 189-213.

Bašić, F., 2013. In: Hartemink, A.E. (Ed.), The Soils of Croatia, World Soil Book Series, International Union of Soil Sciences. Springer Verlag, pp. 142-144.

Berg, T., Steinnes, E., 1997. Use of mosses (Hylocomium splendens and Pleurozium schreberi) as biomonitors of heavy metal deposition: from relative to absolute deposition values. Environ. Pollut. 98, 61-71.

Borovička, J., Kubrová, J., Rohovec, J., Randa, Z., Dunn, C., 2011. Uranium, thorium and rare earth elements in macrofungi: what are the genuine concentrations? BioMetals 24 (5), 837-845. http://dx.doi.org/10.1007/s10534-011-9435-4.

Campos, J.A., Tejera, N.A., Sánchéz, C.J., 2009. Substrate role in the accumulation of heavy metals in sporocarps of wildfungi. BioMetals 22, 835-841. http:// dx.doi.org/10.1007/s10534-009-9230-7.

Cao, X., Chen, Y., Wang, X., Deng, X., 2001. Effects of redox potential and pH value on 
the release of rare earth elements from soil. Chemosphere 44 (4), 655-661.

Castorina, F., Masi, U., 2015. Rare earth elements and $\mathrm{Sr}-\mathrm{Nd}$ isotopes in mosses from Romagna (Italy) and their environmental significance. Biogeochemistry. http://dx.doi.org/10.1007/s10533-015-0067-6.

Chen, J., Yang, R., 2010. Analysis on REE geochemical characteristics of three types of REE-rich soil in Guizhou Province, China. J. Rare Earth 28, 517-522.

Chiarenzelli, J., Aspler, L., Dunn, C., Cousens, B., Ozarko, D., Powis, K., 2001. Multielement and rare earth element composition of lichens, mosses and vascular plants from the Central Barrenland, Nunavut, Canada. Appl. Geochem. 16, $245-270$.

Chopin, E.I.B., Marin, B., Mkoungafoko, R., Rigaux, A., Hopgood, M.J., Delannoy, E., Cancès, B., Laurain, M., 2008. Factors affecting distribution and mobility of trace elements $(\mathrm{Cu}, \mathrm{Pb}, \mathrm{Zn})$ in a perennial grapevine (Vitis vinifera L.) in the Champagne region of France. Environ. Pollut. 156 (3), 1092-1098.

Ćujić, M., Dragović, S., Sabovljević, M., Slavković-Beškoski, L., Kilibarda, M., Savović, J., Onjia, A., 2014. Use of mosses as biomonitors of major, minor and trace element deposition around the largest thermal power plant in Serbia. Clean (Weinh) 42 (1), 5-11.

Das, N., 2005. Heavy metal biosorption by mushrooms. Nat. Rad. 4 (6), 454-459.

De Nicola, F., Spagnuolo, V., Baldantoni, D., Sessa, L., Alfani, A., Bargagli, R. Monaci, F., Terracciano, S., Giordano, S., 2013. Improved biomonitoring of airborne contaminants by combined use of holm oak leaves and epiphytic moss. Chemosphere 92, 1224-1230.

Dilna Damodaran, R., Mohan, B., Vidya Shetty, B.M., 2011. Mushrooms in the remediation of heavy metals from soil. Int. J. Environ. Pollut. Contr. Manag. 3/1, 89-101.

Dołegowska, S., Migaszewski, M., 2013. Anomalous concentrations of rare earth elements in the moss-soil system from south-central Poland. Environ. Pollut. 178, 33-40.

El-Ramady, H.R., 2008. A Contribution on the Bio-actions of Rare Earth Elements in the Soil/plant Environment [Dissertation]. aus dem Julius Kühn-Institut, Berlin.

ERM-CD281-Certification report on Certified Reference Material ERM-CD281, European Comission, Joint Research Center, Institute for Reference Materials and Measurements (IRMM), Geel, Belgium.

Falandysz, J., Frankowska, A., Mazur, A., 2007. Mercury and its bioconcentration factors in King Bolete (Boletus edulis). J. Environ. Sci. Health Part A 42 , 2089-2095. http://dx.doi.org/10.1007/s00253-012-4552-8.

Fedele, L., Plant, J.A., De Vivo, B., Lima, A., 2008. The rare earth element distribution over Europe: geogenic and anthropogenic sources. Geochem. Explor. Environ. A 8 (1), 3-18. http://dx.doi.org/10.1144/1467-7873/07-150.

Fiket, Ž., Mikac, N., Kniewald, G., 2016. Mass fractions of forty-six major and trace elements, including rare earth elements, in sediment and soil reference materials used in environmental studies. Geostand. Geoanal. Res. http://dx.doi.org/ 10.1111/ggr.12129.

Filipović Marijić, V., Raspor, B., 2012. Site-specific gastrointestinal metal variability in relation to the gut content and fish age of indigenous european chub from the Sava river. Water Air Soil Poll. 223 (8), 4769-4783.

Gandois, L., Agnan, Y., Leblond, S., Séjalon-Delmas, N., Le Roux, G., Probst, A., 2014. Use of geochemical signatures, including rare earth elements, in mosses and lichens to assess spatial integration and the influence of forest environment. Atmos. Environ. 95, 96-104. http://dx.doi.org/10.1016/j.atmosenv.2014.06.029.

Gromet, P.L., Dymek, P.F., Haskin, L.A., Korotev, R.L., 1984. The North American shale composite: its composition, major and minor element characteristics. Geochim. Cosmochim. Acta 48 (12), 2469-2482.

HRN EN ISO 11260:2012, 2012. Soil Quality - Determination of Effective Cation Exchange Capacity and Base Saturation Level Using Barium Chloride Solution, p. 14 (ISO 11260:1994+Cor 1:1996; EN ISO 11260:2011).

Johannesson, K.H., Lyons, W.B., Yelken, M.A., Gaudette, H.E., Stetzenbach, K.J. 1996 Geochemistry of the rare-earth elements in hypersaline and dilute acidic natural terrestrial waters: complexation behavior and middle rare-earth element enrichments. Chem. Geol. 133, 125-144.

Kalač, P., 2010. Trace element contents in European species of wild growing edible mushrooms: a review for the period 2000-2009. Food Chem. 122, 2-15. http:// dx.doi.org/10.1016/j.foodchem.2010.02.045.

Kalač, P., Svoboda, L., 2000. A review of trace element concentrations in edible mushrooms. Food Chem. 69, 273-281.

Liang, T., Zhang, S., Wang, L., Kung, H.-T., Wang, Y., Hu, A., Ding, S., 2005. Environmental biogeochemical behaviors of rare earth elements in soil-plant systems. Environ. Geochem. Health 27, 301-311. http://dx.doi.org/10.1007/s10653-0045734-9.

Marović, G., Franić, Z., Senčar, J., Bituh, T., Vugrinec, O., 2008. Mosses and some mushroom species as bioindicators of radiocaesium contamination and risk assessment. Coll. Antropol. 32, 109-114.

Mesić Kiš, I., Karaica, B., Medunić, G., Romić, M., Šabarić, J., Balen, D., Šoštarko, K., 2016. Soil, bark and leaf trace metal loads related to the war legacy (The Prašnik rainforest, Croatia). Min-Geol-Pet. Eng. Bull. http://dx.doi.org/10.17794/ rgn.2016.2.2.

Mleczek, M., Niedzielski, P., Kalač, P., Siwulski, M., Rzymski, P., Gąsecka, M., 2015. Levels of platinum group elements and rare-earth elements in wild mushroom species growing in Poland. Food Addit. Contam. Part A 33 (1), 86-94. http:/ dx.doi.org/10.1080/19440049.2015.1114684.

Onianwa, P.C., 2001. Monitoring atmospheric metal pollution: a review of the use of mosses as indicators. Environ. Monit. Assess. 71 (1), 13-50. http://dx.doi.org 10.1023/A:1011660727479.

Pourret, O., Gruau, G., Dia, A., Davranche, M., Molénat, J., 2010. Colloidal control on the distribution of rare earth elements in shallow groundwaters. Aquat. Geochem 16, 31-59.

Rossbach, M., Jayasekera, R., Kniewald, G., Thang, N.H., 1999. Large scale air monitoring: lichen vs. air particulate matter analysis. Sci. Tot. Environ. 232, 59-66.

Rühling, A., Tyler, G., 2004. Changes in the atmospheric deposition of minor and rare elements between 1975 and 2000 in south Sweden as measured by moss analysis. Environ. Pollut. 131, 417-423.

Salminen, R., Batista, M.J., Bidovec, M., Demetriades, A., De Vivo, B., De Vos, W. Duris, M., Gilucis, A., Gregorauskiene, V., Halamic, J., Heitzmann, P., Lima, A., Jordan, G., Klaver, G., Klein, P., Lis, J., Locutura, J., Marsina, K., Mazreku, A., O'Connor, P.J., Olsson, S.Å., Ottesen, R.T., Petersell, V., Plant, J.A., Reeder, S. Salpeteur, I., Sandström, H., Siewers, U., Steenfelt, A., Tarvainen, T., 2005. FOREGS Geochemical Atlas of Europe, Part 1: Background Information, Methodology and Maps. Geological Survey of Finland, Espoo, p. 526. Available online at: http://www.gtk.fi/publ/foregsatlas/.

Schumacher, B.A. 2002. Methods for the determination of total organic carbon (TOC). In: Soils and Sediments. United States Environmental Protection Agency, Las Vegas, p. 23.

Semhi, K., Osman, A.E., Al Khirbash, A.S., Khan, T., Asaidi, S., Farooq, S., 2009. Mobility of rare earth elements in the system soils-plants-groundwaters: a case study of an arid area (Oman). Arab. J. Geosci. 2, 143-150.

Sesli, E., Tuzen, M., Soylak, M., 2008. Evaluation of trace metal contents of some wild edible mushrooms from Black sea region, Turkey. J. Hazard. Mater. 160 (3) 462-467. http://dx.doi.org/10.1016/j.jhazmat.2008.03.020.

Sonke, J.E., Salters, V.J.M., 2006. Lanthanide-humic substances complexation. I Experimental evidence for a lanthanide contraction effect. Geochim. Cosmochim. Acta 70, 1495-1506.

Šparica, M., Buzaljko, R., Jovanović, Č., 1984. Geology of Nova Gradiška Sheet (L33 107). Basic geological map of Yugoslavia, 1:100000. Institute of Geology, Zagreb nstitute of Geology, Sarajevo, Beograd (Federal institute of Geology) (in Croat).

Srivastava, S., Takur, I.S., 2006. Biosorption potency of Aspergillus Niger for removal of chromium (VI). Curr. Microbiol. 53, 232-237. http://dx.doi.org/10.1080 09593330.2011 .551842

Stern, J.C., Sonke, J.E., Salters, V.J.M., 2007. A capillary electrophoresis-ICP-MS study of rare earth elements complexation by humic acids. Chem. Geol. 246, 170-180.

Tack, M.G., 2010. Trace elements: general soil chemistry, principles and processes. n: Hood, P. (Ed.), Trace Elements in Soil. Wiley, West Sussex, UK, pp, 9-38.

Tuzen, M., Soylak, M., 2005. Mercury contamination in mushroom samples from Tokat, Turkey. Bull. Environ. Contam. Toxicol. 74, 968-972.

Tyler, G., 2004. Rare earth elements in soil and plant systems - a review. Plant Soil 267, 191-206.

Tyler, G., Olsson, T., 2001. Concentrations of 60 elements in the soil solution as related to the soil acidity. Eur. J. Soil Sci. 52/1, 151-165.

Vuković, G., Aničić Urošević, M., Pergal, M., Janković, M., Goryainova, Z., Tomašević, M., Popović, A., 2015. Residential heating contribution to level of air pollutants (PAHs, major, trace, and rare earth elements): a moss bag case study. Environ. Sci. Pollut. Res. http://dx.doi.org/10.1007/s11356-015-5096-0.

Wang, Z.G., Yu, X.Y., Zhao, Z.H., 1989. The Geochemistry of Rare Earth Elements Science Press, Beijing.

Wu, Z.H., Luo, J., Guo, H.Y., Wang, X.R., Yang, C.S., 2001. Adsorption isotherms of lanthanum to soil constituents and effects of $\mathrm{pH}$, EDTA and fulvic acid on adsorption of lanthanum onto goethite and humic acid. Chem. Spec. Bioavailab. $13,75-81$.

Zechmeister, H.G., Grodzinska, K., Szarek-Lukaszewska, G., 2003. Bryophytes. In: Markert, B., et al. (Eds.), Bioindicators and Biomonitors. Elsevier, Amsterdam, pp. 329-375. 